\title{
Kajian Yuridis Penyelesaian Sengketa Medik di Indonesia
}

\author{
Supeno \\ Fakultas Hukum Universitas Batanghari Jambi \\ Jl. Slamet Riyadi Broni Jambi \\ Correspondence email: msasyabani@gmail.com
}

\begin{abstract}
Abstrak. Semakin tinggi tingkat pendidikan dan kesejahteraan masyarakat akan menjadikan tingkat kesadaran hukum masyarakat semakin tinggi pula, dalam konteks kekinian pelayanan kesehatan tidak hanya dipandang sebagai suatu hubungan biasa tetapi sudah menjadi suatu hubungan hukum antara tenaga kesehatan dan pasien, dalam hubungan tersebut dapat terjadi sengketa antara kedua belah pihak, kenyataannya banyak kasus/sengketa medik yang langsung diproses secara pidana, hukum Indonesia telah mengatur bahwa jika terjadi suatu kasus maka dapat diselesaikan melalui jalur hukum administrasi, perdata dan pidana, tujuan penelitian ini adalah untuk mengkaji prioritas utama penyelesaian sengketa medik jika terjadi dugaan kesalahan dan/atau kelalaian yang dilakukan oleh tenaga kesehatan. Tulisan ini merupakan gagasan dan kajian hukum yang penulis kupas secara normatif. Hasil kajian menunjukkan bahwa jika terjadi dugaan kesalahan dan/atau kelalaian yang dilakukan oleh tenaga kesehatan harus diperiksa terlebih dahulu oleh majelis kehormatan dan diupayakan sedapat mungkin diselesaikan secara mediasi.
\end{abstract}

Kata kunci: Sengketa Medik, Majelis Kehormatan, Mediasi

Abstract. The higher level of education and welfare of the community will make the level of legal awareness of the community higher too, in the present context health care is not only seen as an ordinary relationship but has become a legal relationship between health workers and patients, in that relationship disputes can occur between the two sides parties, in fact many cases / medical disputes are directly processed criminally, Indonesian law has stipulated that if a case occurs then it can be resolved through administrative, civil and criminal law, the purpose of this study is to examine the main priorities of medical dispute resolution in case of suspected error and / or negligence committed by health workers. This paper is an idea and legal study that the author peels normatively. The results of the study indicate that if there is a suspicion of error and / or negligence made by a health worker must be checked first by an honorary assembly and sought as far as possible mediated.

Keywords: Medical Disputes, Honorary Council, Mediation

\section{PENDAHULUAN}

Kewajiban Negara untuk melindungi segenap bangsa Indonesia dan seluruh tumpah darah Indonesia dapat diimplemetasikan dalam bentuk perlindungan di bidang hukum yaitu dengan cara menetapkan peraturan perundang-undangan yang dapat melindungi hak-hak warga negara. Dalam Pasal 28D Ayat (1) Undang-Undang Dasar 1945 yang sudah diamandemen diatur bahwa "setiap orang berhak atas pengakuan, jaminan, perlindungan, dan kepastian hukum yang adil serta perlakuan yang sama di hadapan hukum". Dengan menetapkan suatu aturan perundang-undangan dalam kehidupan bernegara maka negara telah menjalankan salah satu kewajibannya yaitu memberikan perlindungan secara hukum dalam bentuk tindakan preventif terhadap warganegaranya, salah satu hal yang pokok dalam kepentingan warganegara adalah hak untuk memperoleh pelayanan kesehatan.

Sehat (health) menurut Webster's New Explorer Encyclopedic Dictionary: adalah a. the condition of being sound in body, mind, or spirit: especially : freedom from physical disease or pain, $b$. the general condition of the body (in poor health), ${ }^{1}$ sehat adalah keadaan dari badan, fikiran dan jiwa, khususnya bebas dari penyakit atau kesakitan, keadaan umum dari badan (kurang sehat). Jadi jika badan, fikiran dan jiwa terbebas dari sakit maka kondisi tersebut dinamakan sehat.

Secara universal kesehatan termasuk dalam pernyataan sedunia tentang hak asasi manusia (universal declaration of human rights) yang tertuang dalam artikel $25,{ }^{2}$ yang menegaskan bahwa setiap orang berhak mendapatkan pelayanan dan perawatan kesehatan bagi dirinya dan keluarganya, jaminan ketika tidak memiliki pekerjaan, sakit, cacat, menjanda, usia lanjut atau kekuarangan nafkah yang disebabkan oleh hal-

\footnotetext{
${ }^{1}$ Merriam Webster, Webster's New Explorer Encyclopedic Dictionary, Federal Street Press, Springfield, 2006, page.844

${ }^{2}$ Artkel 25 Pernyataan sedunia tentang hak Asasi Manusia: Everyone has the right to a standard of living adequate for the health and well-being of himself and of his family, including food, clothing, housing and medical care and necessary social services, and the right to security in the event of unemployment, sickness, disability, widowhood, old age or other lack of livelihood in circumstances
} 
hal di luar kemampuannya. Kesehatan merupakan kebutuhan yang penting dan mendasar bagi setiap manusia, kebutuhan akan kesehatan meliputi kehidupan manusia sepanjang hayat, jika tidak didukung oleh kondisi kesehatan yang baik maka manusia tidak dapat menjalankan segala aktivitas kehidupannya dengan baik pula, oleh karena masalah kesehatan merupakan unsur penting dalam kehidupan manusia maka setiap orang berhak untuk hidup sehat dan memperoleh pelayanan kesehatan serta setiap orang mempunyai kesempatan yang sama dalam memperoleh pelayanan kesehatan. Kesempatan memperoleh pelayanan kesehatan dijamin oleh konstitusi Indonesia yang termuat dalam Pasal 28H ayat (1) UUD 1945: Setiap orang berhak hidup sejahtera lahir dan batin, bertempat tinggal, dan mendapatkan lingkungan hidup yang baik dan sehat serta berhak memperoleh pelayanan kesehatan. Dengan demikian setiap warga Negara Indonesia dijamin haknya untuk hidup sehat dan untuk memperoleh kesempatan yang sama dalam pelayanan kesehatan, artinya hak untuk hidup sehat dan untuk memperoleh pelayanan kesehatan merupakan hak konstitusional setiap warga Negara Indonesia tanpa terkecuali yang harus dihormati oleh setiap orang dan pemerintah wajib melindungi hak warga negara tersebut. Hak atas kesehatan dipertegas lagi dalam Pasal 4 Undang-Undang Nomor 36 Tahun 2009 Tentang Kesehatan yang mengatur bahwa Setiap orang berhak atas kesehatan. Hal tersebut dapat diartikan adanya penegasan pentingnya perlindungan hak atas kesehatan bagi semua orang. Di samping itu kesehatan juga merupakan kewajiban setiap orang untuk berperilaku hidup sehat sebagaimana yang termaktub dalam Pasal 11 yang mengatur bahwa setiap orang berkewajiban berperilaku hidup sehat untuk mewujudkan, mempertahankan, dan memajukan kesehatan yang setinggitingginya. Atas dasar ketentuan di atas maka masalah kesehatan tidak hanya menjadi tanggung jawab pemerintah, tenaga kesehatan dan sarana kesehatan akan tetapi menjadi tanggung jawab setiap orang agar kehidupan manusia menjadi berkualitas.

Jika ditinjau secara khusus, kesehatan menyangkut semua segi kehidupan manusia dan ruang lingkupnya sangat luas, dalam sejarah perkembangannya telah terjadi perubahan orientasi pemikiran mengenai upaya pemecahan masalah kesehatan, proses perubahan tersebut sejalan dengan perkembangan ilmu pengetahuan, teknologi dan sosial budaya masyarakat sehingga upaya kesehatan tidak hanya sekedar penyembuhan saja akan tetapi menyangkut upaya-upaya yang luas, menurut Departemen Kesehatan Republik Indonesia bahwa upaya-upaya kesehatan tersebut menyangkut "upaya peningkatan (promotif), pencegahan (preventif), penyembuhan (kuratif) dan pemulihan (rehabilitatif) yang bersifat menyeluruh, terpadu dan berkesinambungan". ${ }^{3}$ Dengan demikian kesehatan tidak hanya proses penyembuhan saja setelah timbulnya penyakit akan tetapi juga mencakup upaya peningkatan kondisi kesehatan, upaya pencegahan kemungkinan timbulnya penyakit, upaya menghindari penyebab timbulnya suatu penyakit dan upaya memulihkan kondisi kesehatan setelah menderita sakit.

Menurut Endang Kusuma Astuti dalam bukunya Transaksi Terapeutik dalam Upaya Pelayanan Medis di Rumah Sakit menyatakan bahwa:

Hukum kedokteran (kesehatan) bertumpu dan berdasarkan atas dua hak asasi yaitu:

1) Hak atas pemeliharaan kesehatan (the right of health care).dan

2) Hak untuk menetukan nasib sendiri (the rights to self determination) ${ }^{4}$

Dalam hubungan antara pasien dengan dokter tidak jarang terjadinya sengketa antara dokter dan pasien terutama gugatan yang diajukan oleh pasien terhadap dokter dan rumah sakit. Menurut M.C. Inge Hartini sebagaimana yang dikutip oleh Muladi:

Dalam majalah Tempo edisi Maret 2004 serangkaian gugatan pasien terhadap dokter maupun rumah sakit muncul ke permukaan. Tampak fenomena ini akan semakin meningkat seiring dengan peningkatan pendidikan dan kesadaran masyarakat akan hak-haknya. ${ }^{5}$

Dalam konteks hukum setiap orang berhak untuk menuntut pihak lain jika diduga telah merugikan dirinya atau keluarganya, fenomena menunjukkan bahwa gugatan terhadap dokter semakin meningkat hal tersebut tidak terlepas dari semakin tinggi tingkat pendidikan dan kesadaran masyarakat akan hak-haknya maka semakin tinggi pula gugatan pasien terhadap dokter maupun rumah sakit, sehingga gugatan kepada

${ }^{3}$ Depkes RI, Sistem Kesehatan Nasional, Jakarta, 1987, hal.3.

${ }^{4}$ Endang Kusuma Astuti, Transaksi Terapeutik dalam upaya Pelayanan Medis di Rumah Sakit, Citra Aditya Bakti, Bandung, 2009, hal.169

${ }^{5}$ Muladi, Hak Asasi Manusia, Refika Aditama, Bandung, 2009, hal.186. 
dokter/rumah sakit harus diselesaikan di Pengadilan bahkan langsung diproses secara pidana, apakah tidak ada alternatif lain?.

Untuk itu penulis akan mengkaji secara yuridis bagaimana penyelesaian sengketa medik di Indonesia dengan rumusan masalah, pertama bagaimanakah hubungan hukum antara pasien dengan dokter/rumah sakit dan bagaimanakah cara penyelesaian sengketa medik di Indonesia.

\section{HASIL DAN PEMBAHASAN}

\section{Hubungan Hukum Antara Pasien dengan Tenaga Kesehatan}

Secara umum hubungan hukum mempunyai pengertian sebagai hubungan antara dua subjek hukum atau lebih di mana hak dan kewajiban di satu pihak berhadapan dengan hak dan kewajiban di pihak lain, sedangkan subjek hukum secara umum dapat diartikan sebagai pendukung hak dan kewajiban, subjek hukum dibagi atas 2 (dua) macam yaitu manusia (naturlijke person) dan badan hukum (rechts person), "manusia (naturlijke person) adalah setiap manusia yang sejak dilahirkan sampai meninggal dunia sebagai subjek hukum, badan hukum (rechts persoon) adalah tiap pendukung hak dan kewajiban yang bukan manusia". 6

Hubungan hukum antara pasien dengan rumah sakit bermula dari Transaksi Terapeutik, pada saat pasien datang ke rumah sakit untuk berkosultasi tentang kondisi kesehatannya terjadi komunikasi antara pasien dengan dokter, pasien menyampaikan keluhannya dan dokter menyampaikan upaya apa yang dapat dilakukan dokter terhadap pasiennya (informed concent), kemudian pasien menginginkan suatu tindakan dari dokter dan sebaliknya dokter menawarkan tindakan yang dapat dilakukan dokter beserta kemungkinankemungkinan yang akan terjadi, pada saat itulah sebenarnya terjadi suatu transaksi terapeutik, pada saat pasien dan dokter sepakat/menyetujui tindakan yang akan dilakukan maka pada saat itulah sebenarnya terjadinya persetujuan tindakan terapeutik/ kontraktual. Perlu dipahami bahwa dimulainya hubungan hukum antara pasien dengan dokter/rumah sakit yaitu pada saat tercapainya kesepakatan antara kedua belah pihak.

Menurut Hendrojono Soewono dalam bukunya Perlindungan Hak-hak Pasien dalam Transaksi Terapeutik mengatakan:

Pada hakekatnya, persetujuan atas dasar informasi atau yang dikenal dengan istilah informed consent merupakan alat untuk memungkinkan penentuan nasib sendiri berfungsi di dalam praktik dokter. Penentuan nasib sendiri adalah nilai, sasaran dalam informed consent. Secara konkrit persyaratan informed consent adalah: untuk setiap tindakan baik yang bersifat diagnostik maupun terapeutik, pada asasnya diperlukan persetujuan pasien yang bersangkutan. ${ }^{7}$

Pasien harus menyampaikan dengan jujur tentang apa yang dirasakan atau penyakit yang dideritanya kepada dokter, berdasarkan informasi tersebut maka dokter akan melakukan pemeriksaan terhadap pasien, setelahnya dokter harus menyampaikan secara jujur dan lengkap tentang hasil diagnostic, upaya yang dapat dilakukan dan alternatifnya (second opinion), kemungkinan-kemungkinan yang akan terjadi dan peluang untuk sembuh, berdasarkan informasi tersebut maka pasien harus mengambil apakah akan menerima tawaran yang disampaikan oleh dokter tersebut (the right to self determination), setelah terjadi kesepakatan pada saat itulah terbentuknya transaksi terapeutik.

Menurut Pasal 1313 KUH Perdata: Persetujuan adalah suatu perbuatan di mana satu orang atau lebih mengikatkan diri terhadap satu orang lain atau lebih. Pasal tersebut menjadi dasar hubungan antara pasien dan dokter/Rumah Sakit dimana kedua belah pihak terikat terhadap persetujuan yang dicapai dan persetujuan tersebut menjadi undang-undang bagi kedua belah pihak (Pasal 1338 KUH Perdata), dengan demikian persetujuan yang telah disepakati akan menimbulkan akibat hukum bagi kedua belah pihak. Persetujuan yang dibuat harus memenuhi persyaratan sebagaimana yang diatur dalam Pasal $1320 \mathrm{KUH}$ Perdata yaitu:

1. Adanya kesepakatan dari kedua belah pihak, dalam hal ini disebut persetujuan tindakan medis. Persetujuan dapat berupa :

\footnotetext{
${ }^{6}$ Mudjiono, Pengantar Ilmu Hukum Indonesia, Liberty, Yogyakarta, 1991, hal. 45.

${ }^{7}$ Hendrojono Soewono, Perlindungan Hak-hak Pasien dalam Transaksi Terapeutik, Srikandi, Surabaya, 2006, hal. 42.
} 
a. Dinyatakan (expressed concent) baik secara lisan maupun tertulis, tindakan tertulis biasanya untuk tindakan yang mengandung resiko tinggi seperti bedah.

b. Tersirat atau dianggap telah diberikan persetujuan (implied concent), yaitu dalam keadaan normal dan darurat (Permenkes Nomor 585). Munir Fuady mengemukakan bahwa dalam hukum kontrak ada yang disebut kontrak tersamar secara hukum (implied in-law contract) yaitu "kontrak tersamar secara hukum ini merupakan satu-satunya jenis kontrak yang sebenarnya sama sekali tidak ada unsur kesepakatan kehendak di antara kedua belah pihak, tetapi oleh hukum diasumsi adanya unsur

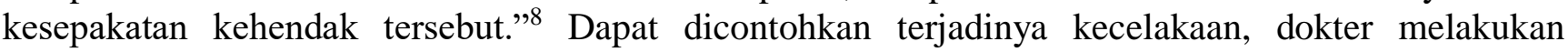
pertolongan terhadap korban yang tidak sadar maka setelah sembuh tanpa diminta, korban selayaknya membayar biaya pengobatan yang telah dilakukan oleh dokter walaupun sebelumnya tidak ada persetujuan tentang upaya tersebut.

2. Kecakapan para pihak, dalam hal ini kedua belah pihak harus cakap untuk membuat kesepakatan, pasien di bawah umur harus mendapat persetujuan dari orangtua/wali/keluarga dekat/induk semang.

3. Suatu pokok persoalan/objek tertentu, Dalam hukum hal ini objek perjanjiannya adalah inspanningsverbintenis (objeknya adalah mencari cara terbaik untuk kesembuhan pasien) bukan resultaatsverbintenis (objeknya hasil).

4. Suatu sebab yang halal/sah, untuk menentukan halal/sahnya atau tidaknya suatu perjanjian dapat dinilai dari 2 (dua) unsur yaitu:

a. Berdasarkan perjanjian, bahwa apa yang diperjanjikan tidak boleh bertentangan dengan kesusilaan dan ketertiban umum seperti kesepakatan untuk menggugurkan kandungan.

b. Berdasarkan hukum, tidak boleh bertentangan dengan ketentuan hukum yang berlaku.

Akibat hukum dari hubungan antara pasien dengan dokter/Rumah Sakit dapat berupa tuntutan ganti rugi karena salah satu pihak wanprestasi dan jika terjadi kesalahan berupa kesengajaan (intentional), kecerobohan (recklessness) atau kealpaan (negligence), berdasarkan asas "Barangsiapa merugikan orang lain, harus memberikan ganti rugi" (Pasal 1365 KUH Perdata).

Aspek kesengajaan dapat diartikan sebagai suatu tindakan dari dokter yang sengaja yang mengenyampingkan apa yang sepatutnya dokter lakukan, sebagai suatu kewajiban jabatan yang tidak boleh ditiadakan atau dikesampingkan, ada beberapa indikator yang menjadi pegangan dokter dalam menjalankan tugasnya yaitu:

1. Kewajiban moral yang tertuang dalam sumpah jabatan dokter bahwa dokter akan mendahulukan kepentingan kemanusiaan dan mengutamakan keselamatan pasien, dalam asas hukum kesehatan dikenal istilah Agroti salus lex suprema: bahwa keselamatan pasien adalah hukum yang tertinggi

2. Kewajiban hukum yang tertuang dalam peraturan perundang-undangan yang berlaku secara umum maupun khusus

3. Kewajiban mematuhi kode etik profesi dokter yang tertuang dalam KODEKI (Kode Etik Kedokteran Indonesia)

4. Kewajiban mematuhi hospital by law yang ditetapkan oleh rumah sakit

5. Kewajiban melaksanakan tugas sesuai dengan batas kewenangannya

6. Kewajiban melaksanakan Standar Pelayanan Medik (SPM)

7. Kewajiban melaksanakan Standar Operational Procedur (SOP)

Sumpah jabatan, peraturan, kode etik, hospital by law, batas kewenangan, Standar Pelayanan Medik dan Standar Operasional Prosedur harus menjadi pedoman dan pegangan dokter dalam menjalankan tugasnya melayani pasien, dengan demikian dugaan melakukan kesengajaan (intentional) dapat dihindari.

Menurut Bahder Johan nasution dan Sri Warjiyati dalam bukunya Bahasa Indonesia Hukum menyatakan bahwa pengertian kealpaan adalah:

Kealpaan adalah dapat diartikan sebagai kurang/tidak mengadakan praduga dan kurang/tidak mengadakan kehati-hatian yang perlu menurut hukum, karena kurang memperhatikan akibat-akibat yang tiba-tiba dan kurang menduga-duga yang perlu, karena lalai atau kurang memikirkan kemungkinan akan timbulnya korban, akibat kelalaiannya. ${ }^{9}$

\footnotetext{
${ }^{8}$ Munir Fuady, Hukum Kontrak dari Sudut Pandang Hukum Bisnis, PT. Citra Aditya Bhakti, Bandung, 1999, hal.51.

${ }^{9}$ Bahder Johan Nasution dkk, Bahasa Indonesia Hukum, Citra Aditya Bakti, Bandung, 2001, hal. 89
} 
Pada dasarnya dokter seharusnya mampu untuk melaksanakan tugasnya dengan baik berdasarkan keilmuan yang dimilikinya, sesuai dengan prasarana, sarana dan alat kesehatan yang tersedia, akan tetapi akibat kurang hati-hati, kurang memperkirakan akibat yang akan ditimbulkan contohnya jika terlambat menangani pasien akan menimbulkan akibat fatal bagi pasien, dalam keadaan seperti inilah dokter telah melakukan kelalaian dan akibat kelalaiannya berdasarkan pasal 1366 KUHPerdata harus mengganti kerugian, kerugian yang dialami oleh pasien/keluarganya dapat berupa kematian, kecacatan ataupun kerugian materil dan immaterial. Soekidjo Notoatmodjo manambahkan bahwa:

Kelalaian di sini adalah sikap dan tindakan yang kurang hati-hati dan menyimpang dari kelaziman yang berlaku di dalam profesinya. Dalam praktik kedokteran dan kedokteran gigi, kelalaian juga diartikan dengan melakukan tindakan medis di bawah standar layanan medis atau standar profesi kedokteran. ${ }^{10}$

Menurut pandangan beliau kelalaian tidak hanya karena tindakan yang kurang hati-hati akan tetapi kelalaian tersebut juga akibat dari tindakan yang dilakukan oleh dokter tersebut di bawah standar layanan medis atau standar profesi dokter, artinya kelalaian terjadi karena dilakukan oleh dokter yang tidak memiliki kompetensi yang disyaratkan bagi dokter. Hal ini akan menjadi pemikiran bagi pemerintah agar dapat merekrut dokter yang benar-benar memiliki kompetensi yang distandarkan oleh pemerintah.

Perlu dipahami juga bahwa hubungan hukum antara pasien dengan rumah sakit terutama rumah sakit pemerintah termasuk dalam hubungan hukum public karena tenaga kesehatan yang bekerja di rumah sakit bekerja atas perintah tugas jabatan yang diberikan oleh pemerintah, sehingga akibat hukum yang dapat terjadi jika tenaga kesehatan melakukan melakukan kelalaian adalah sanksi administrasi dan sanksi pidana.

Dari pemaparan di atas dapat difahami bahwa hubungan hukum antara pasien dengan dokter yang berkerja atas nama rumah sakit swasta atau praktik mandiri adalah hubungan dalam konteks hukum privat hal tersebut dapat dilihat adanya aspek kesepakatan antara pasien dan dokter dalam yang disebut dengan kontrak terapeutik, sedangkan hubungan hukum antara tenaga kesehatan yang berkerja atas nama rumah sakit pemerintah atau unit pelayanan kesehatan milik pemerintah maka hubungan hukumnya adalah hubungan publik sehingga akibat hukum yang dapat diberikan kepada tenaga kesehatan yang melakukan kelalaian adalah sanksi administratif dan/atau pidana. Dalam kaitannya dengan hubungan hukum antara pasien dengan dokter ada dua hal pokok yaitu berdasarkan perjanjian (ius contracto) dan berdasarkan hukum (ius delicto), pengingkaran dalam ius contracto disebut wanprestasi, sedangkan pelanggaran dalam ius delicto disebut onrechtmatige daad (perbuatan melawan hukum).

\section{Penyelesaian sengketa medik di Indonesia}

Perjanjian antara pasien dengan rumah sakit adalah mencari upaya yang tepat untuk kesembuhan pasien (inspanningverbentenis). "Inspanningsverbentenis, yakni perjanjian upaya, artinya kedua belah pihak yang berjanji berdaya upaya secara maksimal untuk mewujudkan apa yang diperjanjikan". ${ }^{11}$ Dengan demikian dalam konteks ini bukan hasil yang menjadi objek perjanjian tetapi adalah kesepakatan untuk untuk mencari upaya yang tepat dan maksimal untuk kesembuhan pasien.

Sebelumnya telah dipaparkan bahwa hubungan hukum antara pasien dengan dokter terjalin dalam 2 (dua) hal pokok yaitu berdasarkan perjanjian dan berdasarkan atas hukum. Penyimpangan dari perjanjian disebut wanprestasi, menurut Subekti ada empat bentuk wanprestasi yaitu:

1) Tidak melakukan apa yang disanggupi akan dilakukan

2) Melakukan apa yang diperjanjikan tetapi tidak sebagaimana yang diperjanjikan

3) Melakukan apa yang diperjanjikan tetapi terlambat

4) Melakukan sesuatu yang menurut perjanjian tidak boleh dilakukan. ${ }^{12}$

Berdasarkan pendapat Subekti tersebut maka dikatakan dokter melakukan wanprestasi adalah tidak melakukan apa yang sudah disepakati dalam perjanjian karena perjanjian/persetujuan adalah undang-undang bagi kedua belah pihak berdasarkan Pasal 1338 KUHPerdata, melakukan apa yang sudah diperjanjikan

\footnotetext{
${ }^{10}$ Soekidjo Notoatmodjo, Etika dan Hukum Kesehatan, Rineka Cipta, Jakarta, 2010, hal. 167

${ }^{11}$ Bahder Johan Nasution, Hukum Kesehatan Pertanggungjawaban Dokter, Rineka Cipta, Jakarta, 2005, hal. 13.

${ }^{12}$ Subekti, Hukum Perjanjian, Intermasa, Jakarta, 1987, hal. 45.
} 
tetapi tidak sebagaimana yang diperjanjikan, melakukan apa yang diperjanjikan tetapi terlambat dan melakukan sesuatu yang menurut perjanjian tidak boleh dilakukan.

Sedangkan unsur-unsur perbuatan melawan hukum (onrechtmatige daad) dalam konteks hukum perdata menurut Rosa Agustina dalam bukunya Hukum Perikatan (Law of Obligation) adalah:

a. Perbuatan

b. Perbuatan tersebut melawan hukum

c. Ada kesalahan

d. Ada kerugian

e. Terdapat hubungan kausal antara perbuatan dan kerugian ${ }^{13}$

Harus ada suatu perbuatan yang dilakukan oleh seseorang, perbuatan yang dilakukan melanggar aturan hukum, adanya unsur kesalahan yang dilakukan yang menimbulkan kerugian bagi pihak lain dan antara perbuatan di satu pihak dengan kerugian yang dialami oleh pihak lain ada hubungan langsung. sanksi bagi yang merugikan yang diatur dalam Pasal 1365 KUHPerdata yaitu tiap perbuatan melanggar hukum dan membawa kerugian bagi pihak lain harus mengganti kerugian tersebut dan dalam pasal 1366 KUHPerdata diatur bahwa kerugian yang diakibatkan oleh kelalaian atau kesemberonoan harus mengganti kerugian.

Mengapa terjadi sengketa, karena pasien menilai bahwa dokter telah melakukan suatu tindakan, dimana tindakan tersebut adalah perbuatan buruk atau malpraktik, menurut Soekidjo Notoatmodjo:

Malprakti berasal dari kata "mala" artinya salah atau tidak semestinya, sedangkan praktik adalah proses penanganan pasien dari seorang professional yang sesuai dengan prosedur kerja yang telah ditentukan oleh kelompok profesinya. Sehingga malpraktik dapat diartikan melakukan tindakan atau praktik yang salah atau yang menyimpang dari ketentuan atau prosedur yang baku (benar). ${ }^{14}$

Di dalam hukum kesehatan untuk menentukan apakah seorang dokter telah melakukan kesalahan dikenal dengan istilah 4-D yaitu:

1. Duty (kewajiban)

2. Dereliction of that duty (penyimpangan atas kewajiban)

3. Damage (kerugian atau cidera)

4. Direct causation between dereliction of that duty with damage (adanya hubungan langsung antara penyimpangan dengan kerugian atau cidera yang dialami pasien $)^{15}$

Keempat unsur tersebut harus terpenuhi secara secara keseluruhan, bahwa ada dokter yang telah dibebani kewajiban untuk menangani seorang pasien, dokter yang dibebani kewajiban tersebut melakukan penyimpangan baik atas dasar wanprestasi maupun melanggar aturan/prosedur yang harus dilaksanakan, akibat penyimpangan tersebut menimbulkan kerugian bagi pasien seperti kematian atau cidera dan harus dibuktikan bahwa ada hubungan langsung antara terjadinya kematian/cidera tersebut dengan penyimpangan yang telah dilakukan oleh dokter.

Jika dilihat kecenderungan akhir-akhir ini penyelesaian sengketa antara pasien dengan dokter langsung diselesaikan dengan hukum pidana, haruskan seperti demikian? Berdasarkan paparan di atas secara jelas terungkap bahwa sengketa antara pasien dengan dokter masuk dalam ranah hukum perdata, seharusnya hukum pidana ditempatkan sebagai ultimum remidium yang diterapkan jika upaya penyelesaian lain telah diterapkan dan tidak dapat diselesaikan dengan menggunakan hukum administrasi dan perdata.

Dokter dalam menjalankan tugasnya terikat dengan KODEKI (Kode Etik Kedokteran Indonesia), jika ada dugaan dokter melakukan kesalahan dalam tugasnya maka yang diberi kewenangan untuk memeriksa adalah Majelis Kehormatan Disiplin Kedokteran Indonesia (MKDKI) berdasarkan keputusan Konsil Kedokteran Indonesia Nomor 17/KKI/KEP/VIII/2006 Tentang Penegakan Disiplin Profesi Kedokteran, juga diatur dalam Pasal 1 angka 14 Undang-Undang Nomor 29 Tahun 2004 Tentang Praktik Kedokteran: Majelis kehormatan Disiplin Kedokteran Indonesia adalah lembaga yang berwenang untuk menentukan ada tidaknya kesalahan yang dilakukan dokter dan dokter gigi dalam penerapan disiplin ilmu kedokteran dan kedokteran gigi, dan menetapkan sanksi, dan berdasarkan putusan Mahkamah Konstitusi Nomor: 4/PVV-

\footnotetext{
${ }^{13}$ Rosa Agustina dkk, Hukum Perikatan (Law of Obligation), Pustaka Larasan, Denpasar, 2012, Hal. 8

${ }^{14}$ Soekidjo Notoatmodjo, Loc.Cit., hal. 167

${ }^{15}$ Chrisdiono M. Achadiat, Dinamika Etika dan Hukum Kedokteran, EGC, Jakarta, 2006, Hal. 12
} 
V/2007 yang memerintahkan agar sengketa medik diselesaikan terlebih oleh MKDKI jika ada unsur kesalahan maka MKDKI menyampaikan rekomendasi kepada badan peradilan untuk proses hukum.

Upaya untuk menyelesaikan sengketa medik juga sudah diatur secara limitatif dalam Pasal 29 UndangUndang Nomor 36 Tahun 2009 Tentang Kesehatan, pasal tersebut memerintahkan bahwa jika ada dugaan tenaga kesehatan melakukan kelalaian harus diselesaikan secara mediasi, sebagai suatu upaya dengan mengedepankan win-win solution bagi kedua belah pihak yang bersengketa dan penyelesaian sengketa melalui mediasi dapat menyelesaikan masalah dengan cepat, efisien dan efektif. Penyelesaian sengketa secara mediasi diatur dalam Undang-Undang Nomor 30 Tahun 1999 Tentang Arbitrase dan Alternatif Penyelesaian Sengketa dan berdasarkan PERMA Nomor : 1 Tahun 2008.

Dalam proses mediasi dilakukan dengan cara musyawarah untuk mufakat dengan mengedepankan kesepakatan kedua belah pihak dan tidak mencari siapa yang benar dan siapa yang salah, Eddi Junaidi dalam bukunya Mediasi dalam penyelesaian Sengekata Medik menyatakan bahwa"dalam mediasi tidak dicari siapa yang benar atau salah, tetapi lebih untuk menjaga kepentingan-kepentingan masing-masing pihak" ${ }^{16}$ menjaga kepentingan kedua belah pihak menjadi hal yang sangat penting karena jika suatu kasus sampai diselesaikan di pengadilan selain akan menghasilkan siapa yang menang dan siapa yang salah maka bagi pihak yang kalah akan mempengaruhi kepentingan lainnya baik peranan dalam pekerjaan dan jabatan, peranan dalam masyarakat termasuk juga peranan dalam keluarga, acapkali akan terganggu neraca keseimbangan kehidupan kedua belah pihak dan akan menimbulkan kegoncangan baik secara sosial maupun kejiwaan, dengan mediasi hal tersebut dapat dihindari, mediasi pun bukan bertujuan untuk membebaskan seseorang dari kesalahan yang telah dilakukan yang mengakibatkan kerugian bagi pihak lain akan tetapi proses penyelesaian harus tetap bertumpu kepada ganti kerugian. Beberapa pasal yang berhubungan dengan klausula ganti kerugian adalah: Pasal 1365 KUHPerdata: tiap perbuatan melanggar hukum yang membawa kerugian kepada orang lain mewajibkan orang yang karena salahnya menerbitkan kerugian itu mengganti kerugian tersebut, Pasal 1366 KUHPerdata: setiap orang bertanggug jawab, bukan hanya atas kerugian yang disebabkan perbuatan-perbuatan, melainkan juga atas kerugian yang disebabkan kelalaian atau kesemberonoan, Pasal 1371 KUHPerdata: menyebabkan luka atau cacat anggota badan seseorang dengan sengaja atau karena kurang hati-hati, memberikan hak kepada korban, selain untuk menuntut penggantian biaya pengobatan juga untuk menuntut penggantian kerugian yang disebabkan oleh luka atau cacat tersebut, juga penggantian kerugian ini dinilai menurut kedudukan kedudukan dan kemampuan kedua belah pihak dan menurut kedaan, Pasal 58 Ayat (1) UU Nomor 36 Tahun 2009: setiap orang berhak menuntut ganti rugi terhadap seseorang, tenaga kesehatan, dan/atau penyelenggara kesehatan yang menimbulkan kerugian akibat kesalahan atau kelalaian dalam pelayanan kesehatan yang diterimanya.

Seharusnya semua kalangan harus memahami bahwa hukum yang harus ditegakkan terlebih dahulu adalah proses sidang kode etik terlebih dahulu, dalam sidang kode etik ini harus dilakukan penelitian dan pemeriksaan secara mendalam agar ditemukan bukti-bukti yang kuat yaitu:

a. Bentuk kesalahan yang telah dilakukan oleh tenaga kesehatan; apakah kesalahan prosedur, telah merugikan orang lain atau telah menghilangkan nyawa orang lain

b. Kerugian yang dialami oleh pasien; apakah mengakibatkan kematian atau kecacatan

Jika dalam proses sidang kode etik dokter terbukti memenuhi unsur-unsur administratif seperti tenaga kesehatan melakukan tindakan di luar batas kewenangannya, tidak berdasarkan standar pelayanan medik atau tidak melakukan standar operasional prosedur (SOP) maka MKDKI dapat mengambil tindakan administratif terhadap tenaga kesehatan tersebut sesuai dengan peraturan perundang-undangan yang berlaku. Untuk kesalahan yang berkaitan dengan perdata dan pidana maka MKDKI merekomendasikan agar kasus tersebut diteruskan ke pihak yang berwajib.

Jika atas tindakan tenaga kesehatan tersebut telah merugikan pasien maka hal ini sudah masuk dalam aspek hukum perdata, langkah pertama yang perlu ditawarkan adalah upaya mediasi sebagai pelaksanaan amanat Pasal 29 UU Nomor 36 Tahun 2009 Tentang Kesehatan, jika jalur mediasi mengalami jalan buntu maka dipersilahkan pihak yang merasa dirugikan melakukan tuntutan perdata, yang dijadikan dasar dalam melakukan penuntutan perdata ini berdasarkan Pasal 1365 dan 1366 KUHPerdata.

Untuk kasus yang mengakibatkan hilangnya nyawa seseorang akibat tindakan kesengajaan atau kelalaian yang mengakibatkan kematian yang dilakukan oleh tenaga kesehatan baik yang bekerja atas nama

${ }^{16}$ Edi Junaidi. Mediasi Dalam Penyelesaian Sengketa Medik. Rajawali. Jakarta,2011, Hal.12. 
rumah sakit pemerintah atau bekerja atas nama rumah sakit swasta/praktik mandiri maka hal ini termasuk dalam aspek hukum pidana, maka yang dijadikan dasar penuntutan adalah Pasal 359, 360 atau 361 KUHPidana.

Tujuan penulis memaparkan masalah ini adalah agar semua elemen dapat menerapkan prinsip primum remidium (hukum administrasi dan hukum perdata) dan prinsip ultimum remidium yang menempatkan hukum pidana sebagai jalan terakhir dalam upaya menyelesaikan sengketa medik dan juga untuk membangun budaya hukum yang baik di dalam masyarakat.

Mengacu kepada teori Lawrence Friedmen bahwa syarat hukum dapat berjalan secara efektif harus memenuhi 3 (tiga) komponen yaitu: 1. Substansi hukumya harus baik, 2. Pranata hukumnya harus baik dan, 3. Budaya hukumnya harus baik. Dalam tataran mana yang perlu untuk diprioritaskan?, tanpa menyengampingkan faktor substansi dan pranatanya faktor budaya hukum harus mendapatkan prioritas yang lebih besar karena budaya langsung menyentuh akar rumput masyarakat paling bawah, hukum akan mendapatkan pengakuan dari masyarakat, dan hukum akan efektif dipatuhi oleh masyarakat, artinya hokum memiliki keberlakuan secara sosiologis karena faktor sosiologis sangat mempengaruhi efektifitas hukum itu, "bentuk keberlakuan pertama adalah keberlakuan sosial atau keberlakuan faktual. Disini berkenaan dengan efektifitas atau "wirksamkeit" dari kaedah hukum"17 diperkuat lagi oleh Zainuddin Ali dalam bukunya Filsafat Hukum, beliau menyatakan bahwa:

Kaedah hukum berlaku secara sosiologis, apabila kaedah tersebut efektif. Artinya, kaedah itu dapat dipaksakan berlakunya oleh penguasa walaupun tidak diterima oleh warga masyarakat (teori kekuasaan), atau kaedah itu berlaku karena adanya pengakuan dari masyarakat. ${ }^{18}$

Penekanan kearah pembentukan budaya hukum ini sangatlah penting karena hukum membutuhkan kesadaran untuk taat hukum bukan sesuatu yang harus dipaksakan tetapi karena diakui dan satu cara yang sudah hidup dalam masyarakat Indonesia tidak sulit untuk melaksanakannya karena budaya tersebut sesuai dengan jiwa orang Indonesia dalam menyelesaikan masalah. Lili Rasyidi dalam bukunya Dasar-dasar Filsafat dan Teori Hukum menyatakan bahwa:

Agar dalam pelaksanaan perundang-undangan yang bertujuan untuk pembaharuan itu dapat berjalan sebagaimana mestinya, hendaknya perundang-undangan yang dibentuk itu sesuai dengan apa yang menjadi inti pemikiran aliran sociological jurisprudence, yaitu hukum yang baik hendaknya sesuai dengan hukum yang hidup di dalam masyarakat. Jadi mencerminkan nilai-nilai yang hidup di masyarakat. Sebab jika ternyata tidak, akibatnya ketentuan tersebut akan tidak dapat dilaksanakan (bekerja) dan akan mendapatkan tantangan-tantangan. ${ }^{19}$

Mainstream masyarakat sebenarnya sudah mulai terbangun dengan penyelesaian sengketa secara mediasi ini karena selain kembali kepada kearifan bangsa juga bangsa Indonesia tidak begitu suka yang formal termasuk dalam menyelesaikan suatu masalah hukum, masyarakat cenderung ingin masalah yang dialami cepat diselesaikan. Kalau dilihat fungsi hukum sebagai Dispute Settlement (berfungsi untuk menyelesaikan masalah) hukum harus mempunyai kharisma atau wibawa dalam menyelesaikan suatu permasalahan kalau tidak hukum akan menjadi boneka penguasa ataupun aparat penegak hukum, hukum tidak berperan.

Salah satu keunggulan yang menonjol dari penyelesaian sengketa melalui mediasi adalah interest based, yaitu dalam mediasi tidak mencari siapa yang benar dan siapa yang salah tetapi lebih untuk menjaga kepentingan-kepentingan masing-masing pihak. "Bagaimanapun juga, hukum mengatur kepentingan masyarakat", ${ }^{20}$ semakin terjaga kepentingan masyarakat semakin efektif hukum itu dilaksanakan, semakin membudaya suatu bentuk penyelesaian sengketa efektif hukum itu diterapkan dan semakin dekatlah apa

${ }^{17}$ Meuwissen, Tentang Pengembanan Hukum, Ilmu Hukum, Teori Hukum, dan Filsafat Hukum, Refika Aditama, Bandung, 2009, Hal. 46

${ }^{18}$ Zainuddin Ali, Filsafat Hukum, Sinar Grafika, Jakarta, 2010, Hal.84

${ }^{19}$ Lili Rasjidi dkk, Dasar-Dasar Filsafat dan Teori Hukum, Citra Adiyta Bakti, Bandung, 2012, Hal.79-80

${ }^{20}$ Munir Fuadi, Filsafat dan Teori Hukum Postmodern, Citra Aditya Bakti, Bandung, 2005. Hal. 153 
yang dituju oleh hukum yaitu untuk mendapatkan kepastian, ketertiban dan keadilan.

\section{KESIMPULAN}

1. Hubungan hukum yang terjalin antara pasien dengan dokter yang dilakukan atas nama rumah sakit swasta/praktik mandiri adalah hubungan dalam ranah hukum privat, sedangkan hubungan hukum yang dilakukan oleh tenaga kesehatan dengan pasien dimana tenaga kesehatan berkerja atas nama rumah sakit pemerintah/unit kesehatan milik pemerintah adalah hubungan dalam ranah hukum publik.

2. Penyelesaian sengketa medik yang harus dilakukan adalah dengan melaksanakan tahapan sebagai berikut:

a. Sidang administratif oleh MKDKI untuk melihat apakah ada unsur kesengajaan atau kelalaian yang dilakukan oleh tenaga kesehatan, dah hasilnya sanksi administrasi dan rekomendasi

b. Penyelesaian hukum secara perdata, jika ditemukan kerugian yang dialami oleh pasien, sedapat mungkin dilakukan penyelesaian hukum secara mediasi

c. Penyelesaian hukum secara pidana jika ditemukan unsur kesengajaan dan/atau kelalaian yang mengakibatkan derita fisik pasien

\section{DAFTAR PUSTAKA}

\section{Buku}

Bahder Johan Nasution,. 2005. Hukum Kesehatan Pertanggungjawaban Dokter. Rineka Cipta. Jakarta. .., 2001. Bahasa Indonesia Hukum. Citra Aditya Bakti. Bandung.

Chrisdiono M. Achadiat.2006. Dinamika Etika dan Hukum Kedokteran, EGC, Jakarta.

Depkes RI. 1987. Sistem Kesehatan Nasional. Jakarta.

Edi Junaidi. 2011. Mediasi Dalam Penyelesaian Sengketa Medik. Rajawali. Jakarta.

Endang Kusuma Astuti.2009. Transaksi Terapeutik dalam upaya Pelayanan Medis di Rumah Sakit. Citra

Aditya Bakti. Bandung.

Gunawan Wijaya dan Ahmad Yani. 2003. Hukum Arbitrase. Raja Grafindo Persada. Jakarta.

Hendrojono Soewono.2006. Perlindungan Hak-hak Pasien dalam Transaksi Terapeutik. Srikandi. Surabaya. H. Sudiarto, Zaeni Asyhadie. 2004. Mengenal Arbitrase Salah Satu Alternatif Penyelesaian Sengketa Bisnis. Raja Grafindo Persada. Jakarta.

Lili Rasjidi dkk. 2012. Dasar-Dasar Filsafat dan Teori Hukum. Citra Adiyta Bakti. Bandung.

Merriam Webster. 2006. Webster's New Explorer Encyclopedic Dictionary. Federal Street Press. Springfield.

Meuwissen.2009. Tentang Pengembanan Hukum, Ilmu Hukum, Teori Hukum, dan Filsafat Hukum. Refika Aditama. Bandung.

Mudjiono.1991. Pengantar Ilmu Hukum Indonesia. Liberty. Yogyakarta.

Muladi. 2009. Hak Asasi Manusia. Refika Aditama. Bandung.

Munir Fuadi. 2005. Filsafat dan Teori Hukum Postmodern. Citra Aditya Bakti. Bandung. 1999. Hukum Kontrak dari Sudut Pandang Hukum Bisnis. . Citra Aditya Bhakti. Bandung.

Rosa Agustina dkk, 2012. Hukum Perikatan (Law of Obligation), Pustaka Larasan, Denpasar.

Soekidjo Notoatmodjo. 2010. Etika dan Hukum Kesehatan. Rineka Cipta. Jakarta.

Subekti. 1987. Hukum Perjanjian. Intermasa. Jakarta. 1987.

Syahrizal Abbas. 2009. Mediasi Dalam Perspektif Hukum Syariah, Hukum Adat, dan Hukum Nasional.

Kencana. Jakarta.

United Nation Organization. 1948. Universal Declaration of Human Rights.

Zainuddin Ali. 2010. Filsafat Hukum. Sinar Grafika. Jakarta.

\section{Peraturan Perundang-undangan}

\section{Undang-undang}

Republik Indonesia, UU Nomor 30 Tahun 1999 Tentang Arbitrase dan Alternatif Penyelesaian Sengketa (Lembaran Negara Republik Indonesia tahun 1999 Nomor 138)

Republik Indonesia, UU Nomor 36 Tahun 2009 Tentang Kesehatan (Lembaran Negara Republik Indonesia tahun 2009 Nomor 144) 